\title{
CRKL Gene
}

National Cancer Institute

\section{Source}

National Cancer Institute. CRKL Gene. NCI Thesaurus. Code C18375.

This gene plays a role in cell communication and signal transduction. 